\title{
NIKAH SIRI DALAM PERSPEKTIF KOMPILASI HUKUM ISLAM DAN UNDANG-UNDANG PERKAWINAN INDONESIA
}

\author{
Kharisudin \\ Fakultas Hukum, Universitas Wijaya Kusuma Surabaya \\ e-mail:kharisudin1979@gmail.com
}

\begin{abstract}
ABSTRAK
Nikah Siri merupakan pernikahan yang dilakukan dengan menggunakan ketentuan-ketentuan yang sudah digariskan dan ditentukan agama atau harus memenuhi syarat-syarat secara adat dengan memenuhi persyaratan-persyaratan yang ditentukan akan tetapi tidak dicatatkan, jadi pernikahan tersebut dianggap sah oleh sebagian masyarakat namun dianggap tidak sah oleh negara. Dalam penulisan ini penulis melakukan penelitian dengan tujuan agar diketahui persepsi hukum terhadap nikah siri dari sudut Kompilasi Hukum Islam dan Undang-Undang Perkawinan di Indonesia. Pendekatan dalam penulisan karya ilmiah ini dilakukan dengan menggunakan statute approach. Kompilasi Hukum Islam menyebutkan nikah siri adalah nikah yang tidak sah, disini akan lebih jelas lagi bagaimana aturan hukum yang ada bisa menjadi tidak sama dengan pemahaman yang ada di masyarakat. Faktor personal antara lain karakteristik masyarakat dalam memahami nikah siri yang dijadikan sebagai alasan pembenar, sedangkan faktor tingkat kesadaran hukum yaitu tingkat pemahaman hukum masyarakat dan aturan yang ada dan berlaku di Indonesia khususnya UU Nomor 1 Tahun 1974 serta KHI kurang begitu diperhatikan. Hasil dari penelitian ini adalah pemahaman konsekuensi hukum yang ditimbulkan dari nikah siri ditunjukkan dengan adanya kasus yang terjadi pada nikah siri ini.
\end{abstract}

Kata Kunci: Nikah siri; UU 1/1974; KHI

\section{ABSTRACT}

Siri marriage is a marriage that is carried out using conditions that have been outlined and determined by religion or must meet customary requirements by fulfilling specified conditions but are not enforced, so the marriage is dependent on a part of society but is not legal by the state. The writing of this research conducted research with the aim of knowing the legal perceptions of unregistered marriage from the perspective of Compilation of Islamic Law and the Marriage Law in Indonesia. The approach in this scientific paper is carried out using a statutory approach. The Compilation of Islamic Law states that unregistered marriage is illegitimate marriage. Personal factors are another reason for the community to understand unregistered marriage which is used as a justifying awareness factor, while the level of legal awareness, namely the level of understanding of community law and existing and applicable rules in Indonesia, especially Law Number 1 of 1974 and KHI was not given much attention. The result of this research is an understanding of the legal consequences of marriage as indicated by the cases that occur in this unregistered marriage.

Keywords: Siri marriage; Law 1/1974; KHI 


\section{PENDAHULUAN}

Pernikahan adalah sebuah ritual sakral dan harus disahkan oleh hukum agama juga hukum negara. Pernikahan yang dilangsungkan atau dilaksanakan seyogyanya dirayakan oleh sebagian besar masyarakat sangat diinginkan, hal itu dimaksudkan untuk memberitakan suatu peristiwa yang menggembirakan tersebut, juga sebagai sarana untuk mempublikasikan legalitas baru yang mereka dapatkan sebagai sepasang suami istri yang sah. Ada juga orang yang menginginkan pernikahannya dirahasiakan serta melangsungkannya secara siri. Nikah siri merupakan proses pernikahan yang dirahasiakan, dan dalam pelaksanaannya berdasarkan aturan agama atau adat istiadat saja.

Menurut terminologi, menikah berarti berkumpul menjadi satu, adapun menurut syar'i (peraturan dalam Islam) adalah akad atau perjanjian yang mempunyai unsur dibolehkannya untuk melakukan hubungan badan dengan memakai lafadz nikah atau ijab dan qobul. ${ }^{1}$

Adapun pengertian nikah menurut Kompilasi Hukum Islam (KHI) dirumuskan sebagai berikut; Pernikahan secara Islam ialah ijab qabul yang kuat untuk mentaati perintah-perintah Allah SWT dan barangsiapa melaksanakan pernikahan berarti dia telah melaksanakan salah satu perintah Allah SWT. ${ }^{2}$

Pernikahan siri merupakan pernikahan yang dirahasiakan, dalam arti tidak ada pemberitahuan atau pengumuman atas pernikahan tersebut pada khalayak atau masyarakat. Pada umumnya nikah siri dilaksanakan hanya dihadapan seorang ustadz atau seorang tokoh adat dan tidak dilaporkan ke Kantor Urusan Agama (KUA). Nikah siri menjadi masalah dan sampai sekarang sering terjadi di Indonesia, karena tidak diketahui pihak yang berwenang.

Undang-Undang No. 1 Tahun 1974 pada Pasal 2 ayat (2) menyebutkan dengan tegas bahwa setiap pernikahan harus dicatatkan sesuai dengan hukum yang berlaku, dengan demikian maka dapat dipahami jika nikah siri adalah suatu perbuatan atau pernikahan yang tidak boleh dilakukan dan apabila dilakukan maka tidak akan diakui oleh negara karena tidak

\footnotetext{
${ }^{1}$ Fatihudin Abul Yasin. (2006). Risalah Hukum Nikah. Edisi Revisi. Jakarta: Terbit Terang, h. 14.

${ }^{2}$ Amin Suma Muhammad. (2005). Hukum Keluarga Islam di Dunia. Jakarta: PT. Rajagrafindo Persada, h. 46.
}

tercatat dan jelas melanggar ketentuan yang terdapat dalam Undang-Undang Perkawinan.

Selanjutnya yang menjadi persoalan adalah pembuktian adanya pernikahan tersebut yang menurut Undang-Undang dibuktikan dengan Kutipan Akta Pernikahan yang diterbitkan oleh KUA atau Catatan Sipil, sehingga ketika sebuah pernikahan tidak dilaksanakan dihadapan petugas yang ditunjuk, maka akan kesulitan terhadap pembuktian pernikahannya, karena tidak tercatat pada institusi yang berwenang, hal ini sudah diatur oleh UU 1/1974, bahwa "Tiaptiap pernikahan dicatat menurut peraturan undangundang yang berlaku". ${ }^{3}$

Di Indonesia telah diatur hubungan pernikahan dengan diterbitkannya Undang-Undang tentang Pernikahan. Undang-undang tersebut menjadi pelaksanaan tentang adanya hak asasi manusia yang berhubungan dengan pernikahan itu sendiri. Apabila ditelaah ulang pernikahan siri adalah merupakan ajaran Islam, akan tetapi pada aturan UU 1/1974 pernikahan tersebut adalah bentuk perkawinan yang dilarang. Yang selanjutnya diciptakan daftar pernikahan yang dilarang dan tidak diakui sah oleh negara. Apabila dilihat dari aspek HAM maka pernikahan tersebut menjadi legal. Sehingga sampai sekarang pernikahan siri tetap menjadi perdebatan yang sengit di banyak kalangan. ${ }^{4}$

Maka sebenarnya ada dua sisi yang menarik untuk diamati dalam pernikahan siri yang terjadi di masyarakat, dengan adanya peraturan perundangundangan yang ada sudah menetapkan aturan pernikahan dan di sisi yang lain pernikahan merupakan hak asasi manusia yang patut untuk dihormati. Dari sini bisa didapatkan beberapa hal termasuk sebuah konsekuensi hukum dari pernikahan siri tersebut, dimana anak yang dari pernikahan ini akan mempunyai ikatan perdata hanya dari jalur ibu saja, serta bukan menjadi ahli waris atau tidak ada hubungan perdata dengan ayahnya.

Masyarakat terbagi menjadi dua golongan besar, yang satu mengatakan bahwa pencatatan perkawinan bukan salah satu dari rukun atau syarat

\footnotetext{
${ }^{3}$ https://bimasislam.kemenag.go.id/post/opini/status-nikahsiri-menurut-perundangan-undangan-di-Indonesia, diakses tanggal 18 Maret 2020

${ }^{4}$ Enik Isnaini. "Perkawinan Siri dalam Perspektif Hukum Islam, Hukum Positif dan Hak Asasi Manusia”. Jurnal Independent. Vol. 2 No. 1, h. 52.
} 
sahnya pernikahan. Dari pendapat tersebut kemudian orang yang melakukan pernikahan siri mendapatkan legitimasi. Golongan yang kedua berkeyakinan kalau pencatatan nikah merupakan kewajiban baru untuk menjadikan sahnya pernikahan. Jika melihat pendapat yang kedua ini berdasar pada mudharat yang lebih besar bila suatu pernikahan tidak dicatatkan. Sebab kalau suatu pernikahan tersebut tidak dicatatkan maka tidak ada jaminan hukum terhadap kedua mempelai yang melaksanakan pernikahan siri tadi. ${ }^{5}$

Suatu saat nanti apabila dalam suatu perkawinan siri mendapatkan anak, maka tentunya sebagai seorang Warga Negara Indonesia harus patuh dan tunduk pada hukum Indonesia. Dalam hal ini apabila anak tersebut akan melaksanakan perkawinan dan membutuhkan seorang wali, maka ini akan menjadi masalah baru yang timbul dari suatu perkawinan siri. Demikian pula dengan hal waris tentunya juga akan timbul masalah baru yang semua itu bermuara pada perkawinan siri. ${ }^{6}$

Ilustrasi untuk Saddu Dzari'ah, seperti contoh adanya larangan berkholwat (di tempat yang sepi) antara laki-laki dan perempuan yang bukan muhrim. Hal tersebut dilarang karena akan menimbulkan fitnah, meskipun laki-laki dan perempuan yang bukan muhrim tadi tidak melakukan apa-apa. Begitu pula seorang laki-laki dilarang mengawini wanita sekaligus memadukannya dengan saudara atau bibinya karena bisa memutus hubungan keduanya. Begitu pula nikah dengan tidak adanya bukti serta pencatatan nikah dapat menjadikan kemudaratan bila terjadi urusan dengan hukum atau yang lain yang sangat membutuhkan bukti atas terjadinya suatu pernikahan. $^{7}$

Nikah siri menurut Islam dianggap sah oleh kebanyakan masyarakat, namun tidak sah oleh karena tidak sesuai dengan hukum negara Indonesia. Konsep dan tafsir terhadap pernikahan siri tetap menggema sepanjang masa dan dengan tetap "merahasiakan" suatu pernikahan. Sedangkan makna nikah siri dalam ajaran agama Islam adalah satu wujud substantif,

\footnotetext{
${ }^{5}$ Moh. Amin. "Dualisme Hukum Nikah Siri di Indonesia dalam Perspektif Fiqih Indonesia (Refleksi 42 Tahun UndangUndang No. 1 Tahun 1974 tentang Perkawinan)”. Jurnal Studi Keislaman. Vol. 15 Nomor 1 Juni 2015, h. 3.

${ }^{6}$ Ahmad Sobari. "Nikah Siri Dalam Perspektif Islam". Mizan: Jurnal of Islamic Law. Volume 1 No 1 Juni 2013. https:// doi.org/10.32507/mizan.v1i1.117

${ }^{7}$ ibid.
}

didalamnya ada kurang syarat serta rukun pernikahan walaupun secara formal terlihat syarat pernikahan itu sudah terpenuhi.

Sementara dari aspek sosiologis masyarakat dalam spektrum perundangan akan memaknai bahwa nikah siri adalah sebuah pernikahan yang tidak dicatatkan oleh KUA atau kantor catatan sipil. Demikian persepsi yang berkembang di masyarakat dan sampai sekarang persepsi tersebut masih ada dan berkembang secara luas.

\section{PERUMUSAN MASALAH}

Dengan didasarkan pada uraian dalam latar belakang tersebut, penulis merumuskan permasalahan bagaimana nikah siri menurut perspektif Kompilasi Hukum Islam dan UU Perkawinan Indonesia?

\section{METODE PENELITIAN}

Penelitian yang dilakukan oleh penulis adalah penelitian normatif yang berarti penelitian ini meneliti mengenai sisi undang-undang yang berhubungan, tidak meneliti gejala sosial akibat aturan yang ada. Sedangkan metode pendekatan yang dipakai dalam penelitian ini adalah pendekatan perundangundangan (statute approach).

Pendekatan ini dipakai, sebab pada penelitian ini pembahasan dilakukan dengan merujuk pada norma perundang-undangan di Indonesia agar dapat ditemukan jawaban yang bersifat normatif dan preskriptif, sebagaimana sifat dari ilmu hukum itu sendiri.

\section{PEMBAHASAN}

Pada dasarnya pernikahan merupakan legitimasi yang menyatukan antara seorang laki-laki dan seorang perempuan sebagai pasangan suami istri yang benar berdasarkan aturan negara Indonesia. Dan model pernikahan yang tidak sesuai serta tidak dipenuhinya legal procedure yaitu nikah siri. Duraiwisy mengatakan kalau siri itu berasal dari kata "sir" atau "sirrun" yang berasal dari bahasa Arab yang berarti sunyi atau rahasia. Nikah siri menurut makna diksi berarti pernikahan yang proses pelaksanaannya dilakukan secara tersembunyi atau rahasia, selanjutnya pada perkembangannya istilah nikah siri tersebut memiliki ikatan dengan hukum 
negara. Nikah siri berarti sebuah pernikahan yang tidak dicatatkan. ${ }^{8}$

Pernikahan siri ada beberapa macam, diantaranya yaitu nikah dengan tanpa adanya wali. Nikah yang seperti itu terkadang dilaksanakan oleh seseorang secara tersembunyi atau siri, oleh karena wali dari calon pengantin perempuan bisa jadi tidak menyetujui, dan bisa jadi hal itu dilakukan karena keabsahan pernikahan tersebut belum dapat dipenuhi. Dan bisa juga dimungkinkan perkawinan itu hanya berdasarkan sebagai pemuas nafsu saja sehingga tidak mengikuti ajaran syari' at yang sesungguhnya. Pernikahan seperti ini adalah tidak sah, karena adanya wali nikah menjadi salah satu rukun sahnya sebuahpernikahan. ${ }^{9}$

Nikah "siri" banyak diartikan oleh masyarakat dengan; Pertama; pernikahan yang dilakukan dengan tidak adanya wali. Nikah siri dilaksanakan dengan sembunyi-sembunyi oleh karena pihak wali calon pengantin perempuan tidak menyetujui terhadap perkawinan tersebut; dan karena menganggap bahwa pernikahan yang dilaksanakan tanpa wali adalah sah; atau sebab hanya bertujuan memuaskan nafsu semata dengan tidak memperhatikan aturan-aturan syariat agama; yang kedua, nikah siri merupakan pernikahan yang diakui sah oleh agama namun tercatat dalam lembaga pencatat nikah.

Ada banyak faktor yang menjadi sebab seseorang melakukan pernikahan namun tidak mencatatkan pernikahan tersebut di lembaga pencatat nikah. Salah satu dari faktor tersebut adalah karena faktor dana atau biaya, yang berarticalon pengantin tidak mampu untuk bayar biaya pencatatan nikah baik di KUA maupun di catatan sipil; ada juga faktor takut diketahui kalau pernikahan tersebut tidak sesuai dengan aturan karena negara tidak memperbolehkan seorang PNS menikah lebih dari satu; dan masih banyak lagi faktor-faktor yang lain; yang ketiga, nikah itu disembunyikan karena berbagai pertimbangan tertentu; contohnya sebab ketakutan akan mendapat sorotan negatif dari warga yang masih memandang nikah siri adalah sesuatu yang tabu. ${ }^{10}$

\footnotetext{
${ }^{8}$ Siti Aminah. "Hukum Nikah di Bawah Tangan (Nikah Siri)". Cendekia. Vol. 12 Nomor 1 Januari 2014, h. 24.

${ }^{9}$ ibid.

${ }^{10}$ Oky Deviany Burhamzah. "Nikah Siri Dalam Perspektif Hukum Perkawinan Nasional". University of Bengkulu Law Journal (UBELAJ). Vol. 1 No. 1 2016. https://doi.org/10.33369/ ubelaj.1.1.29-44
}

\section{Bentuk Nikah Terlarang}

Dalam hukum islam ada beberapa bentuk pernikahan terlarang, antara lain;

\section{Nikah Mut'ah}

Al Jazairi memberikan definisi "Nikah yang dikaitkan dengan pembatasan waktu tertentu."11 Mut'ah adalah dari bahasa Arab yang berarti kesukaan, kesenangan dan kenikmatan, yang selanjutnya dikembangkan menjadi istilah dalam pernikahan yaitu pernikahan yang dilaksanakan dengan tempo waktu tertentu. Nikah mut'ah akan secara otomatis berhenti atau tidak berlaku kalau masa yang telah disepakati selesai.

\section{Nikah Tahlil}

Pernikahan yang dilakukan oleh seorang laki-laki dengan seorang perempuan yang cerai dengan suaminya dengan talak tiga, pernikahan itu dilakukan dengan niat agar wanita tersebut dihalalkan (diperbolehkan) untuk menikah lagi dengan mantan suaminya, setelah suami yang kedua menceraikannya serta sudah melalui waktu iddah. ${ }^{12}$

Dari definisi di atas diketahui kalau nikah tahlil yang dipergunakan untuk menghalalkan kembali suami yang pertama untuk menikahi kembali istri yang sudah dia ditalak tiga karena sebab terdapat unsur sengaja (niat). Dan bila tidak terdapat niat untuk menjadikan halal, maka suami pertama boleh menikahi kembali mantan istriyang sudah dia talak tiga pasca bekas istrinya tersebut melakukan pernikahan dengan seorang pria lain serta sudah diceraikan dan sudah melewati masa iddahnya.

\section{Nikah Syighar}

Sebelum agama Islam hadir, syighar pada waktu itu diakui sebagai suatu pernikahan, yang selanjutnya setelah agama Islam datang syighar tersebut dilarang oleh Nabi Muhammad SAW, sebab merupakan pernikahan yang menghalangi hal seorang perempuan. Di dalam fiqih Islam, Sayid Sabik memasukan syighar dalam jenis nikah yang dilarang. Para Fuqaha sebagian memberikan pengertian bahwa syighar adalah: orang yang mengawinkan perempuan berada di bawah perwaliannya dengan tidak ada mahar di

\footnotetext{
${ }^{11}$ Madzhib Al Arba'ah 4, h. 90.

${ }^{12}$ Ahmad Sobari. op.cit.
} 
antara mereka. ${ }^{13}$ Para ulama menyepakati bahwa

Pernikahan seperti itu adalah tidak sah, terlarang dan akadnya batal.

Dari ketiga bentuk pernikahan yang dilarang tersebut, dapat dilihat kalau pernikahan-pernikahan tersebut dengan jelas dilarang dalam agama Islam maka setiap muslim tidak boleh melakukannya sebagaimana dijelaskan dalam hukum Islam bahwa tidak diperbolehkannya melakukan sesuatu adalah berarti larangan.

Nikah siri atau biasa kita pahami sebagai perkawinan yang dilakukan secara rahasia, tidak tercatat atau nikah yang dilakukan secara ilegal dari dulu dan sampai sekarang merupakan hal yang kontroversi. Selain merupakan hal yang kontroversi dalam kehidupan warga masyarakat, hukum atas pernikahan ini merupakan sesuatu yang belum bisa diterima baik menurut hukum Islam ataupun hukum positif. Dalam kitab fiqih kuno ada terdapat penjelasan tentang nikah siri meskipun secara istilah nikah siri di dalam kitab fiqih tersebut beda kalau ditinjau prakteknya sekarang. Di Indonesia, nikah siri tidak dikenal di dalam hukum positif, karena negara Indonesia secara hukum menjalankan aturan hukum bahwa suatu perkawinan harus di catat di hadapan pegawai pencatat akta nikah. Ini juga adalah sesuai dengan Kompilasi Hukum Islam (KHI) yang keberadaannya diberlakukan.

Fakta-fakta menunjukkan kalau pemahaman tentang nikah siri ini sebenarnya sangat popular di masyarakat. Masyarakat mengartikan dan memahami bahwa suatu pernikahan yang dalam pelaksanaannya tidak tercatat sebagaimana ketentuan hukum negara maka itu diartikan sebagai nikah siri. Sementara peraturan negara menjelaskan kalau pencatatan dalam sebuah perkawinan adalah merupakan syarat sah.

Pelaksanaan nikah siri sangat bertentangan dengan ajaran agama Islam yang menganggap bahwa perkawinan merupakan suatu ikatan yang kuat juga sakral serta penuh dengan nilai-nilai agama. Sehingga pada proses pelaksanaan nilai-nilai dalam hukum lain secara informal yang ada di dalam masyarakat diabaikan bahkan tidak dipercaya lagi. Karena pada praktiknya negara Indonesia mempunyai aturan hukum atau mazhab tersendiri yang harus

\footnotetext{
${ }^{13}$ Sulaiman Rasjid. (2016). Fiqih Islam 73. Bandung: Sinar Baru Algensindo, h. 47.
}

dilaksanakan oleh semua warga negara yang akan melaksanakan perkawinan.

\section{Nikah Siri Dalam Perpsektif KHI}

Sebagian orang memandang nikah siri adalah pernikahan menurut agama dinyatakan sah, dengan catatan memenuhi semua ketentuan nikah yang ditetapkan oleh agama. Demikian pemahaman yang hingga saat ini sebagian masyarakat masih bersih keras dengan pemahaman itu dengan mengesampingkan pencatatan nikah sesuai dengan peraturan perundangan yang ada dan berlaku.

Pemahaman "menurut hukum agama sah" menjadi penyebab banyaknya orang melakukan nikah siri. Di samping terdapat sikap ragu-ragu atas peraturan tentang perkawinan yang mengatur adanya isbat nikah. Sebagaimana pada Pasal 7 ayat (2) KHI menyebutkan bahwa "dalam hal perkawinan tidak dapat dibuktikan dengan akta nikah, dapat diajukan isbat nikah ke Pengadilan Agama". Selanjutnya pada Pasal 7 ayat (3) menyatakan bahwa "isbat dimaksud pada ayat (2) adalah terbatas dan hanya mengenai hal-hal yang berkenaan dengan:

a. Hal yang dalam rangka penyelesaian perceraian;

b. Adanya kehilangan akta nikah yang dimiliki;

c. Terdapat keraguan dalam suatu perkawainan apakah perkawinan tersebut sah atau tidak;

d. Perkawinan yang dilaksanakan sebelum berlakunya UU Perkawinan No. 1 Tahun 1974;

e. Adanya perkawinan yang dilakukan oleh mereka yang tidakmempunyai halangan perkawinan menurut UU Perkawinan No. 1 Tahun 1974.

Sedangkan Pasal 7 ayat (4) KHI lebih lanjut disebutkan bahwa "yang berhak mengajukan isbat nikah ialah suami isteri, anak-anak mereka, wali nikah dan pihak yang berkepentingan dengan perkawinan itu." 14

Adapun tentang isbat nikah yang disebutkan pada Pasal 7 Kompilasi Hukum Islam, secara eksplisit menjelaskan adanya indikasi pengakuan tentang sahnya pernikahan yang tidak dicatatkan untuk kemudian dapat dicatatkan di kemudian hari. Dan tentunya dengan adanya isbat nikah ini dimaksud supaya nikah siri yang dilakukan dapat dicatatkan dan dapat memberikan keuntungan pada pihak yang dengan sengaja melaksanakannya. Ini banyak dilakukan oleh Pengadilan Agama di Indonesia

\footnotetext{
${ }^{14}$ Kompilasi Hukum Islam. Pasal 7.
} 
dengan dasar yang diperbolehkan oleh KHI. Jika alasan-alasan yang ada di dalam KHI tersebut sudah dilakukan dan dijadikan pedoman pihak Pengadilan Agama, artinya untuk nikah siri bisa dilakukan isbat nikah.

Terdapatnya pengakuan yang secara eksplisit atas pernikahan siri dengan melalui isbat nikah dan adanya idiom "sah menurut hukum agama" pada pokoknya tidak selalu berkaitan atas publikasi pernikahan, meskipun ada hadits Nabi Muhammad SAW yang menganjurkan sebuah pernikahan itu hendaknya diumumkan. Dalam hal terdapat hadits riwayat alTirmidzi dari 'Aisyah RA, bahwa Rasulullah SAW memberikan perintah untuk mengumumkan sebuah perkawinan dengan walimatul 'ursy meskipun hanya menyembelih satu ekor kambing.

Wahbah Al Zuhaily memberikan definisi pernikahan siri adalah dengan adanya ijab-qabul dalam pelaksanaannya terdapat dua orang mempelai (laki-laki dan perempuan), wali nikah dan dua orang saksi. Pada nikah siri, calon pengantin lakilaki boleh memberikan pesan pada saksi untuk menyembunyikan atau merahasiakan perkawinan itu, walaupun terhadap keluarganya sendiri. Madzhab Syafi'i dan madzhab Hanafi membolehkan nikah siri, kemudian madzhab Maliki membolehkan dengan catatan harus dalam situasi atau keadaan darurat, sedangkan madzhab Hanafi menghukumi nikah siri adalah makruh. ${ }^{15}$

Menurut Prof. Quraish Shihab, meskipun nikah siri tidak tercatat dan dinilai sah menurut hukum agama, akan tetapi nikah siri dapat menjadi sebab dosa untuk pelakunya, karena tidak menjalankan yang diterapkan oleh negara dan DPR (selaku Ulil Amri). Al-Qur'an memberikan perintah kepada semua muslim agartaat kepada ulil amri (pemimpin) sepanjang ulil amri tersebut tidak bertentangan dengan hukum-hukum Allah. Pada hal mencatatkan nikah tersebut, tidak hanya bukan bertentangan, malah justru hal tersebut sesuai dengan Al-Qur'an. ${ }^{16}$

Nikah siri dalam arti pernikahan tanpa adanya pencatatan juga terjadi di Mesir yang dikenal dengan istilah al zawaj al 'urfiy. Syekh Ali Jad al Haq yang

${ }^{15}$ Wahbah al Zuhaily. (1989). al Fiqh al Islamiy wa Adillatuh. Beirut: Dar al Fikr, juz VII, h. 71.

${ }^{16}$ Quraish Shihab. (1997). Wawasan Al-Qur'an: Tafsir Maudhu'i atas Pelbagai Persoalan Umat. Bandung: Mizan, h. 204. merupakan salah satu syekh al Azhar memberikan pembagian atas aturan yang mengatur perkawinan menjadi dua, yaitu:

1) Aturan syara' adalah aturan penentu atas sah atau tidak sah suatu pernikahan. Peraturan ini merupakan hasil dari rumusan para ulama mazhab dalam fikih sebagai unsur-unsur pembentuk akad nikah, yaitu: adanya ijab qabul, adanya calon suami, adanya calon istri, adanya wali, dan ada dua orang sebagai saksi;

2) Peraturan tawsiqy adalah peraturan tambahan yang bertujuan agar pernikahan tercatat dalam suatu akta yang legal diterbitkan oleh pegawai yang ditunjuk oleh pemerintah.

Dengan dilakukannya pencatatan nikah, negara bisa melindungi pasangan suami istri yang menikah dari upaya negatif yang akan dilakukan oleh para pihak yang tidak bertanggungjawab. Kendati pernikahan yang sudah memenuhi persyaratan sesuai dengan ketentuan aturan agama tanpa dokumen resmi dianggap sah, akan tetapi kembali pada pendapat Syekh Jad al Haq Ali "peraturan tawsiqy" yang menegaskan bahwa pencatatan perkawinan harus dilakukan oleh semua umat islam yang melakukan pernikahan yang berfungsi untuk antisipasi apabila diperlukan dalam urusan dengan pengadilan. ${ }^{17}$

Legitimasi nikah siri dari aspek perspektif fikih membuka celah praktek nikah siri dalam masyarakat. Dengan tidak dicatatkannya suatu pernikahan akan berdampak pada jaminan kepastian hukum, terlebih untuk perempuan dan anak yang akan dilahirkan dari adanya nikah siri tersebut. Upaya rekonseptualisasi rukun dan syarat pernikahan yang telah dilakukan adalah untuk menghapus praktek nikah siri.

Penambahan pencatatan pernikahan sebagai rukun pernikahan telah dilakukan Tim CLD-KHI dalam RUU tentang Hukum Perkawinan Islam. Pencatatan oleh pihak yang berwajib (pencatat nikah) dimasukkan sebagai salah satu rukun pernikahan dengan adanya dua alasan, yaitu:

1. Berlandaskan pada dalil analogi hukum (qiyas awlawy). Kalau hutang saja melibatkan lebih dari satu orang maka hukumnya wajib untuk dicatat terlebih pada suatu perkawinan yang merupakan suatu peristiwa hukum yang akan berimplikasi pada nasab, kewarisan, dan status sosial; dan

${ }^{17}$ Satria Effendi M. Zein. (2004). Problematika Hukum Keluarga Islam Kontemporer. Jakarta: Prenada Media, h. 33-34. 
2. Berdasarkan dalil sadd al dzari'ah bahwa pernikahan yang tidak tercatat dapat menjadi sebab hilangnya perlindungan hukum bagi seorang perempuan dan anak-anak. ${ }^{18}$

Nikah siri dalam kenyataannya memiliki banyak keburukan daripada kebaikannya, sudah seharusnya masyarakat diberikan edukasi kalau dalam nikah siri ini yang sangat dirugikan adalah perempuan dan anak. Nikah siri yang menurut hukum negara tidak sah ini menyebabkan perempuan dan anak tidak bisa memperoleh haknya. Misalnya terkait harta gonogini apabila suatu saat terjadi perceraian sebab apapun yang terjadi perkawinan itu akan dianggap tidak pernah ada dan terjadi oleh hukum.

Dalam pandangan sosial, laki-laki dan perempuan yang melakukan pernikahan siri seringkali dianggap melakukan kumpul kebo. ${ }^{19}$ Karena pada dasarnya dalam pandangan sosial, seorang perempuan dan laki-laki sebagai pelaku pernikahan siri tersebut tinggal seatap serta tidak adanya ikatan perkawinan sah karena tidak bisa dibuktikan dengan buku nikah sebagai pelaksanaan dari pencatatan suatu perkawinan.

Dimana dalam suatu masyarakat terdapat struktur meaning yang bisa pula dimaknai dengan common value, demikian Weber mengemukakan sebuah konsep. Ini menjelaskan bahwa apa yang dilakukan warga masyarakat tidak akan bisa lepas dari meaning atau value yang ada dan berlaku dalam suatu masyarakat tersebut. Selanjutnya Weber juga menjelaskan bahwa tindakan individu pada dasarnya memiliki tujuan-tujuan khusus.

Hal tersebut merupakan wujud dari suatu upaya untuk memahami sebuah tindakan serta sekaligus upaya memahami tujuan atas tindakan tersebut. Sehingga dalam memahami sebuah tindakan masyarakat itu sudah seharusnya memahami konteks meaning atau value dalam budaya masyarakat itu sendiri.

Nikah siri dilakukan sudah pasti ada sebab yang terkandung, seperti pernikahan jangan sampai diketahui istri sah atau istri pertama. Dalam hukum Islam, apabila perkawinan sudah terpenuhinya rukun

\footnotetext{
${ }^{18}$ Aisyah Arsyad. (2017), "Polemik Nikah Siri: Dualisme Hukum Memapankan Sistem Patriarki”, dalam M. Nabiel (ed.). Muslim Subjectivity: Spektrum Islam Indonesia. Yogyakarta: Pustaka Insan Madani, h. 57.

19 Thriwaty Arsal. "Nikah Siri dalam Tinjauan Demografi". Jurnal Sosiologi Pedesaan. Vol. 6 No. 2 September 2012, h. 166.
}

perkawinan, yaitu dengan adanya wali, ada ijab dan kabul, serta hal yang menghalangi tidak ada menurut agama maka perkawinan tersebut dinyatakan sah.

Oleh karena nikah siri tersebut dilakukan dengan tidak disaksikan oleh pegawai KUA, maka pernikahan tersebut sangat jelas melanggar UU 1/1974. Dalam hal ini, yang mengawinkan dan/atau pasangan pengantin dapat dituntut ke Pengadilan terhadap pelanggaran yang dilakukannya, serta dapat diancam dengan hukuman denda paling tinggi $\mathrm{Rp}$ 7.500,- (tujuh ribu lima ratus rupiah). menurut Pasal 45 ayat (1)a, PP No. 9/1975.20

UU 1/1974 Pasal 2 ayat (1) dan (2) menjelaskan: "Perkawinan hanya sah bila dilakukan menurut agama dan kepercayaannya, dan dicatat menurut peraturan pencatatan yang berlaku.". Selanjutnya, berdasarkan PP No. 9/1975, pada Pasal 2 ayat (1) dan (2) bagi yang beragama Islam dicatatkan di Kantor Urusan Agama, untuk selain Islam dicatatkan pada kantor Catatan Sipil. Mengenai urusan anak, adalah anak sah menurut hukum agama. Tetapi, karena perkawinannya belum sah menurut UU 1/1974, yang artinya belum diterbitkannya akta nikah yang sah dan legal, maka anak yang lahir dari nikah siri tersebut tidak punya bukti yang sah menurut hukum di Indonesia. Permasaalahan lain yang muncul adalah dalam hal urusan waris, akan sukar untuk membuktikan dalam pengertian ia tidak punya alat pembuktian yang sah. ${ }^{21}$

Pada Pasal 5 ayat (1) menyebutkan; "Agar terjamin ketertiban perkawinan bagi masyarakat Islam setiap perkawinan harus dicatat" dan ayat (2) menyebutkan; "Pencatatan perkawinan tersebut pada ayat (1), dilakukan oleh Pegawai Pencatat Nikah sebagaimana yang diatur dalam Undang-Undang No. 22 Tahun 1946 jo. Undang-Undang No. 32 Tahun 1954." ${ }^{22}$

Jadi jelas disini menurut KHI dan UU Perkawinan Indonesia, nikah siri adalah tidak sah karena melanggar peraturan perundangan di Indonesia dan tidak sesuai dengan hukum. Hukum Islam tentang perkawinan sendiri sudah lama dilaksanakan jauh

${ }^{20}$ Iqbal, Mashuri S. dan Li Sufyana M. Bakri. (1994). Mencari Cahaya Dari Ilmu Ulama, Bandung: Sinar Baru Algensindo, h. 128.

${ }^{21}$ ibid.

22 Direktorat Pembinaan Peradilan Agama Islam Ditjen Pembinaan Kelembagaan Islam Departemen Agama. (2001). Kompilasi Hukum Islam di Indonesia. 
sebelum adanya peraturan yang mengharuskan pelegalan catatan akta nikah, sehingga sangat sulit untuk membendung ombak perkawinan siri yang marak terjadi di masyarakat. Meskipun dalam hal ini masih saja menjadi sebuah problematika yang terkait hak perempuan dan si anak yang seringkali menjadi pertanyaan mendasarnya.

Di Indonesia sebenarnya telah ada peraturan yang secara legal sebenarnya sudah bisa menjadi ukuran suatu perkawinan itu sudah sah atau belum. Antara lain secara yuridis adanya usaha untuk melindungi perempuan dari berbagai perilaku ketidakadilan yang sudah diakomodir dalam Deklarasi Universal Hak Asasi Manusia (DUHAM) oleh Majelis PBB tanggal 18 Desember 1948. selanjutnya deklarasi ini dijelaskan dengan lebih rinci melalui konvensi PBB tentang penghapusan semua bentuk diskriminasi pada perempuan yang diumumkan pada tanggal 18 Desember 1979. Selebihnya di tingkat lokal atau negara yang sudah meratifikasi DUHAM, juga konvensi PBB harus menjelaskan selanjutnya yang telah disesuaikan dengan kebutuhan negara masing-masing. Dalam hal ini Indonesia juga turut meratifikasi, sehingga dijabarkan kemudian sesuai kebutuhannya. ${ }^{23}$

\section{Akibat Hukum Nikah Siri}

Nikah siri dalam perspektif KHI dan UU Perkawinan Indonesia jelas dinyatakan sebagai suatu perkawinan yang tidak sah dan bersifat melanggar hukum, oleh karena itu maka akibat hukum yang ditimbulkan dari nikah siri sangat jelas dan yang paling dirugikan atau yang menjadi korban atas perbuatan nikah siri ini adalah perempuan dan anak yang dilahirkan.

Seorang perempuan akan menanggung akibat hukum seperti dalam hal apabila terjadi perceraian atau perpisahan dalam nikah siri maka perempuan tersebut tidak akan bisa menuntut harta bersama yang didapatkan selama terjadinya pernikahan siri tersebut, karena tidak ada bukti adanya suatu perkawinan.

Demikian pula, seorang anak yang dilahirkan dari perkawinan siri tidak bisa menuntut hak waris kepada ayahnya karena secara legalitas hukum anak tersebut

\footnotetext{
${ }^{23}$ Zeni Lutfiyah, dkk. "Perkawinan Siri dalam Reformulasi Hukum Perkawinan Islam di Indonesia Sebagai Upaya Preventif Terhadap Disharmoni Sosial Dalam Masyarakat (Perspektif Gender Dan Hak Asasi Manusia)". Jurnal Yustisia. Edisi 91 Januari-April 2015, h. 108.
}

tidak mempunyai bukti bahwa dia adalah ahli waris disebabkan karena perkawinan orangtuanya tidak dapat dibuktikan dengan tercatatnya perkawinan tersebut yang dalam hukum dinyatakan bahwa perkawinan tersebut tidak pernah ada.

\section{PENUTUP}

\section{Kesimpulan}

Nikah siri yang sudah memenuhi syarat pernikahan menurut agama adalah sah dan memiliki legitimasi hukum agama sesuai Pasal 7 ayat (2) KHI yang menyebutkan bahwa "dalam hal perkawinan tidak dapat dibuktikan dengan akta nikah, dapat diajukan isbat nikah ke Pengadilan Agama” berarti pernikahan siri tersebut diperbolehkan dengan mengajukan isbat nikah di Pengadilan Agama. Di sisi lain, UU 1/1974 menyebutkan bahwa perkawinan yang sah adalah pernikahan yang pelaksanaannya telah sesuai dengan agama dan kepercayaan pengantin serta dicatat menurut ketentuan hukum yang berlaku. Oleh karena itu nikah siri menurut UU Perkawinan dinyatakan tidak sah karena tidak dicatatkan. Akibat hukum dari nikah siri adalah apabila terjadi masalah di kemudian hari maka tidak akan mendapatkan jaminan hukum untuk para pihak, karena negara menganggap bahwa perkawinan tersebut tidak pernah ada karena tidak ada bukti pencatatan perkawinan. Dalam hal ini yang akan menjadi korban adalah perempuan dan anak.

\section{Rekomendasi}

Hendaknya dapat dilakukan edukasi hukum terhadap masyarakat agar terhindar dari pemahaman yang salah tentang nikah siri dan tidak ada pihak yang akan dirugikan sehingga meminimalisir terjadinya sengketa yang berhubungan dengan status hukum anak yang lahir dari nikah siri dan sengketa waris.

\section{DAFTAR PUSTAKA}

\section{Peraturan Perundang-undangan:}

Undang-Undang No. 1 Tahun 1974 tentang Perkawinan.

Deklarasi Universal Hak Asasi Manusia.

Direktorat Pembinaan Peradilan Agama Islam Ditjen Pembinaan Kelembagaan Islam Departemen Agama. (2001). Kompilasi Hukum Islam di Indonesia. 
Peraturan Pemerintah (PP) Nomor 9 tahun 1975 tentang Pelaksanaan Undang-Undang Nomor 1 tahun 1974 tentang Perkawinan.

\section{Buku:}

Aisyah Arsyad. (2017), "Polemik Nikah Siri: Dualisme Hukum Memapankan Sistem Patriarki", dalam M. Nabiel (ed.). Muslim Subjectivity: Spektrum Islam Indonesia. Yogyakarta: Pustaka Insan Madani.

Amin Suma Muhammad. (2005). Hukum Keluarga Islam di Dunia. Jakarta: PT. Rajagrafindo Persada.

Fatihudin Abul Yasin. (2006). Risalah Hukum Nikah. Edisi Revisi. Jakarta: Terbit Terang.

Iqbal, Mashuri S., dan Li Sufyana M. Bakri. (1994). Mencari Cahaya Dari Ilmu Ulama. Bandung: Sinar Baru Algensindo.

Madzhib Al Arba'ah 4.

Quraish Shihab. (1997). Wawasan Al-Qur'an: Tafsir Maudhu'i atas Pelbagai Persoalan Umat. Bandung: Mizan.

Satria Effendi M. Zein. (2004). Problematika Hukum Keluarga Islam Kontemporer. Jakarta: Prenada Media.

Sulaiman Rasjid. (2016). Fiqih Islam 73. Bandung: Sinar Baru Algensindo.

Wahbah al Zuhaily. (1989). al Fiqh al Islamiy wa Adillatuh. Beirut: Dar al Fikr, juz VII.

\section{Jurnal:}

Ahmad Sobari. "Nikah Siri Dalam Perspektif Islam". Mizan: Jurnal of Islamic Law. Volume 1 No 1 Juni 2013. https://doi.org/10.32507/mizan. v1i1.117

Enik Isnaini. "Perkawinan Siri dalam Perspektif Hukum Islam, Hukum Positif dan Hak Asasi Manusia”. Jurnal Independent. Vol. 2 No. 1.

Moh. Amin. "Dualisme Hukum Nikah Siri di Indonesia dalam Perspektif Fiqih Indonesia (Refleksi 42 Tahun Undang-Undang No. 1 Tahun 1974 tentang Perkawinan)". Jurnal Studi Keislaman. Vol. 15 Nomor 1 Juni 2015.

Oky Deviany Burhamzah. "Nikah Siri Dalam Perspektif Hukum Perkawinan Nasional". University of Bengkulu Law Journal (UBELAJ). Vol. 1 No. 1 2016. https://doi.org/10.33369/ ubelaj.1.1.29-44

Siti Aminah. "Hukum Nikah di Bawah Tangan (Nikah Siri)". Cendekia. Vol. 12 Nomor 1 Januari 2014.

Thriwaty Arsal. "Nikah Siri dalam Tinjauan Demografi”. Jurnal Sosiologi Pedesaan. Vol. 6 No. 2 September 2012.

Zeni Lutfiyah, dkk. "Perkawinan Siri dalam Reformulasi Hukum Perkawinan Islam di Indonesia Sebagai Upaya Preventif Terhadap Disharmoni Sosial Dalam Masyarakat (Perspektif Gender dan Hak Asasi Manusia)". Jurnal Yustisia. Edisi 91 Januari-April 2015.

\section{Website:}

https://bimasislam.kemenag.go.id/post/opini/statusnikah-siri-menurut-perundangan-undangan-diIndonesia, diakses tanggal 18 Maret 2020 